Association for Information Systems

AIS Electronic Library (AISeL)

\title{
Local Retail Under Fire: Local Shopping Platforms Revisited Pre and During the Corona Crisis
}

\author{
Soeren Baersch \\ Fachhochschule Südwestfalen \\ Lars Bollweg \\ Fachhochschule Südwestfalen \\ Peter Weber \\ Fachhochschule Südwestfalen \\ Tim Wittermund \\ Fachhochschule Südwestfalen \\ Valerie Wulfhorst \\ Fachhochschule Südwestfalen
}

Follow this and additional works at: https://aisel.aisnet.org/wi2021

Baersch, Soeren; Bollweg, Lars; Weber, Peter; Wittermund, Tim; and Wulfhorst, Valerie, "Local Retail Under Fire: Local Shopping Platforms Revisited Pre and During the Corona Crisis" (2021). Wirtschaftsinformatik 2021 Proceedings. 3.

https://aisel.aisnet.org/wi2021/UDigitalRetail/Track06/3

This material is brought to you by the Wirtschaftsinformatik at AIS Electronic Library (AISeL). It has been accepted for inclusion in Wirtschaftsinformatik 2021 Proceedings by an authorized administrator of AIS Electronic Library (AISeL). For more information, please contact elibrary@aisnet.org. 


\title{
Local Retail Under Fire: Local Shopping Platforms Revisited Pre and During the Corona Crisis
}

\author{
Sören Bärsch ${ }^{1}$, Lars Bollweg ${ }^{1}$, Peter Weber ${ }^{1}$, Tim Wittemund ${ }^{1}$ and Valerie Wulfhorst ${ }^{1}$ \\ ${ }^{1}$ Fachhochschule Südwestfalen, Soest, Germany
\{baersch.soeren, bollweg.lars, weber.peter, Wittemnund.tim, \\ wulfhorst.valerie\}@fh-swf.de
}

\begin{abstract}
The digital transformation is threatening the local stationary retail sector. Local Shopping Platforms (LSPs) were considered as a promising approach to support local owner-operated retail outlets (LOOROs) with their digitalization, but they struggled in utilizing the special characteristics, like e.g., the locational advantages of the affiliated retailers. In this study, we assess the current state of LSPs in Germany in 2020 with the help of a structured content analysis and semi-structured telephone interviews, addressing also the impact of the Covid-19 crisis. Our results show that the preferential platform type has changed. The lockdown has significantly boosted the number of Store Locator Platforms as one type of LSP. Furthermore, it turned out that LSPs with a "Strictly Local Approach" introduce more location-based services than LSPs with a "Scaling Local Approach".
\end{abstract}

Keywords: Local Shopping Platforms, LOOROs, Location-based Services, Location-enabled Services, Coronavirus (COVID-19/SARS-CoV-2) Outbreak

\section{Introduction}

“The Retail Scenario 2030”, as introduced by the Federal Government of North RhineWestphalia and conducted by IFH Köln researchers, has predicted significant changes for the retail landscape within the next decade [1]. On the first view pleasing, the study predicts a revenue increase of $134 \mathrm{~m}$ euros for the entire German retail sector. However, a closer look at the numbers reveals that e-commerce and grocery retailers consume the majority of this growth. Only a small fraction of $1.7 \mathrm{~m}$ euros is assigned to traditional stationary big box retailers and local owner-operated retail outlets (LOOROs). LOOROs can be characterized as shops with small-sized store areas, a limited number of staff and high owner-involvement in the day-to-day business operations [2]. Accordingly, the study predicts a large number of store closings in German cities - up to 64,000 local retailers are at stake [1]. As bad as this prognosis already is for local retailers, the "Retail Scenario 2030" did not yet include the impact of the coronavirus and the according lockdown in early 2020. In fact, many LOOROs thus need to be considered as threatened in their very existence. The retail sector suffers so bad because of its high share of communication-intensive interactions between the sales personnel

16th International Conference on Wirtschaftsinformatik,

March 2021, Essen, Germany 
and the customers, which became impossible because of the social distancing regulations and lacking use of online channels [3], [4]. In numbers: The outbreak of the coronavirus decreased revenues by 2.8\% in March and 6.5\% in April 2020 for the whole retail sector. Even though the revenue has recovered by an increase of $13.9 \%$ in May 2020 , this recovery is mostly driven by e-commerce and the catalog business (+28.7\%) [5], [6]. For LOOROs, revenue decreased strongly by $10.1 \%$ in March 2020, followed by a recovery of $+3.5 \%$ in May 2020. However, this increase did not compensate the losses during the lockdown [6]. Despite the support measurements on the European and national levels, like the pan-European guarantee fund for small and medium-sized European companies, many LOOROs face a tense financial situation [3], [7]. This is alarming as studies show that most LOOROs have a very short survival time of only about eight weeks without or with only very low revenues [8]. Furthermore, a high number of store closings negatively affects the attractiveness of the city centers as shopping locations, triggering or intensifying a downward spiral of less shops and less shoppers leading to less attractive highstreets and less tax income for the cities, resulting in less financial resources to support and develop the city centers [9].

LOOROs and cities need to tackle this downward spiral. Therefore, several independent studies recommend LOOROs to reposition their business models, focusing more on convenience and experience as well as local and digital offers for their customers [1], [10], [11]. Despite these recommendations, the reluctance to transform their businesses stays high among LOOROs because of internal and external adoption barriers (e.g., financial constraints or lack of standards) [12-15]. On the other hand, the coronavirus seems to be a game changer, fostering the willingness of LOORO owners to follow e-commerce trends more than ever. Recent studies show that many local retailers started digital services like click \& collect, same day delivery, or coupons during the lockdown [16].

To offer these digital services, LOOROs often utilize intermediaries like Local Shopping Platforms (LSPs) as service providers or inter-organizational service hubs [17]. LSPs are based on the three main functions of e-marketplaces plus a local focus [17], [18]. Therefore, research on LSPs has many ties to research on e-marketplaces and e-intermediaries (see subchapter 2.1). However, many former studies predicted the failure of LSPs [16], criticizing that they do not help LOOROs attracting more customers to their stores, that they do not utilize the locational advantages of LOOROs as a unique selling proposition, and that they do not help generating higher revenues [17], [19].

Anyhow, LSPs are still out there and there is at least one strong argument in favor of them: LSPs help LOOROs to overcome e-commerce adoption barriers and thus support their digital transformation [20], [21]. But it is still questionable if the services offered by LSPs are enough to sustain LOOROs threatened core business, namely, their physical store. Against this background, it is important to assess how LSPs and their service offers have developed over the last years and if LSPs have started to introduce more services that utilize the locational advantages of LOOROs. For instance, LSPs offer services which utilize the locational proximity between LOOROs and their customers with location-enabled services (e.g., click \& collect, same-day delivery) or location-based services (e.g., location-based discounts) [22]. Furthermore, it is not yet to say, how the corona crisis has affected the development of LSPs with regard to their 
service offers and their role in the digital transformation process of local retail. Moreover, in general, LSPs have been neglected by research so far. Therefore, this paper aims to answer the following research question:

Main RQ) What is the current state of service \& platform type development of LSPs in Germany?

To answer the stated research question, we have derived three sub questions, which will examine the development of LSPs from different viewpoints.

How did the types of German LSPs develop between 2016 and 2019?

RQ2) How did the digital services offered by German LSPs develop

RQ3) between 2016 and 2019?

How has the corona crisis affected the development of LSPs?

To answer RQ1 and RQ2, this paper follows up on a sample from 2016 of a preliminary study using a structured content analysis [17]. RQ3 will be answered using answers from structured telephone interviews.

The paper is structured as follows: In section 2, we discuss the existing literature and the theoretical background. In chapter 3, we introduce the methodological foundation of the two analyses (content analysis and semi-structured telephone interviews). In section 4 , the results will be discussed. Section 5 concludes and identifies limitations and discusses future research opportunities.

\section{Background: Local Shopping Platforms}

Literature on Local Shopping Platforms is scarce. In the following, we introduce the existing literature briefly and build on previous research to derive the necessary theoretical foundations and structures for our analysis.

\subsection{Definition of Local Shopping Platforms}

Local Shopping Platforms (LSP), which act as intermediaries between LOOROs and their customers, are spreading in German cities. The advent of LSPs has many ties to the long tradition of e-marketplaces, which are described as inter-organizational information systems [23]. Previous studies identified LSPs based on the three main functions of e-marketplaces plus a local focus [17], [18]. Accordingly, an LSP must fulfill at least one of the following main functions of e-marketplaces: 1) They match buyers and sellers; 2) They facilitate the exchange of information; 3) They facilitate transaction and fulfillment services [23], [24]. Additionally, their local focus is a main characteristic of LSPs that distinguishes them from traditional e-marketplaces, like Amazon or Rakuten, where regional or national restrictions blur [23], [25]. Accordingly, LSPs are geographically restricted and they target customers living in a defined region or city [26]. Bärsch et al. (2019) specify this local component of LSPs 
and introduce a self-restriction criterion as an identifier: "It is either a limitation to the cooperation with retailers from a certain area, the limitation of just doing business with customers from a certain area, or both." LOOROs join LSPs to attract customers to their premises and to promote their local advantages. They are usually not interested in targeting people from far away and consider this a waste of their advertising budget [26].

Despite these characteristic objectives of LOOROs, the preliminary study indicated that most LSPs adhere to the self-restriction criterion and strictly address only the local market, while some have started experimenting with addressing a national or even global market [17]. Accordingly, the self-restriction criterion can be extended by a business model view, differentiating between a "Strictly Local Approach" and a "Scaling Local Approach", with the latter platforms still focusing on local retailers and local customers while at the same time trying to scale to non-local customers [17].

\section{$2.2 \quad$ Types of LSPs}

As e-marketplaces, LSPs provide a non-standardized and diverse service landscape. This service landscape ranges from an online business card with just information about store opening hours to a full transaction process with pricing, invoicing and logistics [27]. Following the approach of Peterson et al. (2007) and Bärsch et al. (2019), this diverse landscape enables a typological categorization of LSPs based on their emarketplace functionalities and their local focus [17], [18] (see Table 1). Bärsch et al. derived the following types: The first function (match of buyers and sellers) allows for the differentiation of two categories of LSPs, Store Locator Platforms and Product Catalog Platforms. Store Locator Platforms (e.g., "www.like-lippstadt.de") offer only contact information like opening hours and e-mail addresses, whereas Product Catalog Platforms (e.g., "www.bummelbu.de") provide an overview of product information (e.g., size, product photos). For the second function (exchange of information), an additional platform category named Product Enquiry Platforms (e.g., "www.deinhsk.de") can be derived. This platform enables customers to request product availability information and product details, like e.g. sizes, colors or prices. Considering the third function (transaction and fulfillment), two more types can be differentiated. First, Affiliate Transaction Platforms (e.g., "www.koomio.com") enable the purchase of products, but require the completion of transactions on external "affiliate" websites. Second, Full Transaction Platforms (e.g., "www.lozuka.com") offer the full emarketplace service range for transactions, including payment and logistics services.

Table 1: Local Shopping Platform categories with regards to their e-marketplace functionalities, derived from Peterson et al. (2007)

\begin{tabular}{lccc}
\cline { 2 - 3 } & Information & Communication & Transaction \& Fulfillment \\
\hline Store Locator & & Affiliate Transaction \\
Platform & Platforms & Product Enquiry & Platforms \\
Categories & Product Catalog & Platforms & Full Transaction \\
& Platforms & & Platforms \\
\hline
\end{tabular}




\subsection{Categories of Services on LSPs}

In the advent of e-commerce, the location of the retailer seemed to have lost its importance, while it quickly turned out that physical distance still matters, e.g., because of negative effects of growing transportation costs on online sales prices or customer demand for quick delivery [28], [29]. This indicates that the location "is not dead" in the e-commerce age and that it becomes a crucial factor in the rising service competition between pure e-commerce players and stationary retailers [30]. In this context, two categories of digital services can be differentiated, location-dependent and location independent services. Especially location-dependent services (e.g., same-day delivery and click and return) can be considered essential for local retailers to attract and retain customers in multi-channel retail environments [31], [32]. They also have a positive impact on the customers' intention, respectively willingness-to-buy on LSPs [22] and they are positively correlated with repurchases and the loyalty of customers [30].

Location-dependent services can be distinguished into location-enabled and locationbased services. Location-enabled services are "services that are feasible if the location of the retailer is close to the households of the customers (Bärsch et al. 2019, p. 606)". This closeness enables information services (e.g., map with store locations, information about store opening hours or contact data), communication \& support services (e.g., loyalty card, customer integration) and fulfilment services with low transportation costs (e.g., same hour, day delivery, click \& return). Location-based services on the other hand are "services that are feasible if the customers are close to the store location (Bärsch et al. 2019, p. 606)". Examples again range from information services (e.g., barcode scanner or map with store location), to communication \& support services (e.g., price-draws, discounts or support), to navigation services (e.g., in-store navigation, shopping tours or outdoor navigation) and to payment \& billing services (e.g., selfcheckout).

Location-independent services on the other hand include standard web services, like online recommendations (e.g., further products of the retailer), online communication \& support (e.g., service hotline or Facebook communication), or also online payment \& billing services (e.g., credit card payment). These services are not bound to a specific location of the customer and accordingly, they are rampant on all national and global e-marketplaces.

\section{$3 \quad$ Analysis}

The stated research questions with respect to the development of the LSP market and their services were analyzed in two steps. First, we conducted a content analysis to assess the development of the market and the service offers of LSPs. Second, we assessed the potential impact of the corona crisis on LSPs in an explorative manner, conducting 26 semi-structured telephone interviews with executive managers of selected LSPs (see subchapter 3.5). 


\subsection{Development of LSPs: Methodology}

In line with previous research, we conducted an extensive content analysis to examine the development of the market and the service offers of LSPs [17]. In order to achieve comparable results to the preliminary study of Bärsch et al. (2019), we followed the guidelines by Krippendorff (1980, 2004) [33], [34] and Mayring (2010) [35]. Accordingly, after defining the research scope and questions, in a first step, we have identified the existing LSPs through an explorative web search. In the second step, we have conducted a pre-test in order to achieve coding consistency. This pre-test was followed by a revision procedure to improve the categorization and to streamline the coding agenda. In the fourth step, three individual coders have conducted a full content analysis. In the fifth step, the verification for the intercoder reliability of the coding results followed. Finally, an expert panel of senior researchers resolved inconsistencies within the coding results (see Figure 1).

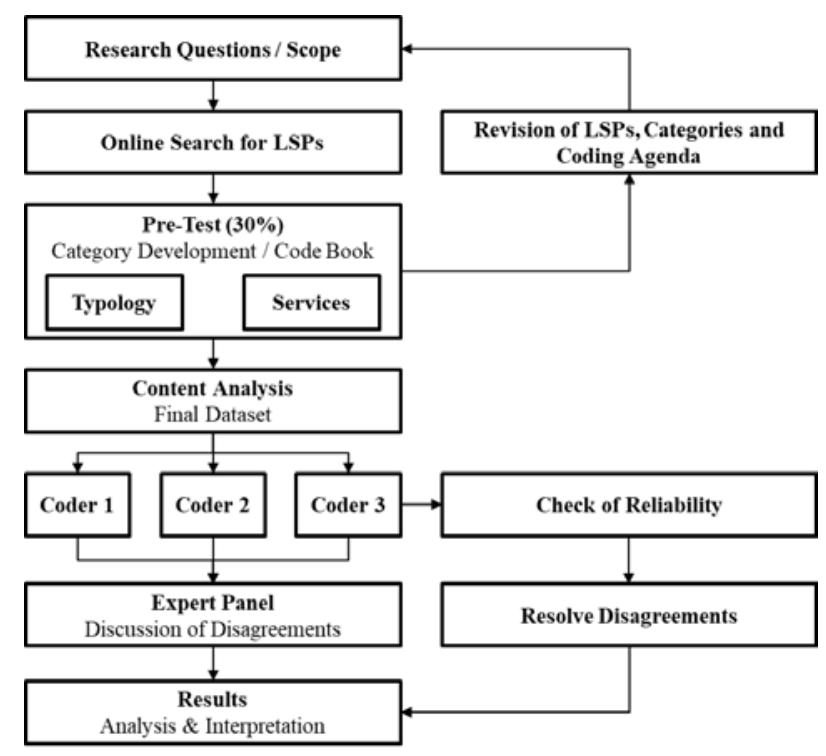

Figure 1. Research Procedure (based on Krippendorff 2004 and Mayring 2010).

\subsection{Development of LSPs: Sample of the Content Analysis}

For the identification of LSPs in Germany, we used the following keyword combinations for the explorative web search in German: "Local + (E-Marketplace, Shopping Platforms, Shops Online, Vendors Online, Marketplace, Products Online, Retail Online, Online Shop, Retailer Archive, Product Archive, Product Enquiry), Buy Local + City Name". The online search process was conducted via the search engine Google in October 2019. The search process resulted in a first set of 179 candidates for Local Shopping Platforms. However, 77 platforms were excluded for several reasons, e.g., because they were inactive, or addressed business customers rather than 
consumers. This selection and screening process resulted in a final set of 102 LSPs for the content analysis.

\subsection{Development of LSPs: Pre-Test \& Coding of the Content Analysis}

A pre-test (30\%) for the categories and the services of LSPs has been conducted to ensure consistent coding. Based on the results of the pre-test, we identified 74 possible items: 5 typological items and 69 service items. Contrary to Bärsch et al. (2019), we changed the location-independent service offerings of two service items due to the pretest findings. We deleted Google + (the site is down) as a service item for the category communication \& support and added "Klarna" (new finding) as a service item for the category payment. For the coding procedure, we created a codebook with a description of each item. Three coders that were different from the ones in the previous study performed the coding and the content analysis between November 1, 2019 and December 22, 2019 [17]. The three coders screened each platform for all 74 possible items, with each item being rated “ 1 ” if Yes / Available and " 0 ” if No / Not Available.

\subsection{Development of LSPs: Intercoder Reliability of the Content Analysis}

The intercoder reliability was verified according to the guidelines of Raupp and Vogelsang (2009) [36] and Tinsley and Weiss [37], [38]. Therefore, the Holsti's Coefficient of Reliability $r_{H}$, and Krippendorff's $\alpha$ were calculated to verify the results for the typological items and the service items [34]. With 5 typology items and 102 platforms to screen, each coder judged 510 typology items in total. The three coders achieved a very good intercoder reliability for the Holsti's Coefficient [39] and an acceptable Krippendorff's $\alpha$ [34].

Table 2: Intercoder Reliability for Typology and Service Items

\begin{tabular}{|l|c|c|c|c|c|c|}
\hline & \multicolumn{3}{|c|}{ Typology Items } & \multicolumn{3}{c|}{ Service Items } \\
\hline Coder Pair & $\mathrm{C} 1+\mathrm{C} 2$ & $\mathrm{C} 1+\mathrm{C} 3$ & $\mathrm{C} 2+\mathrm{C} 3$ & $\mathrm{C} 1+\mathrm{C} 2$ & $\mathrm{C} 1+\mathrm{C} 3$ & $\mathrm{C} 2+\mathrm{C} 3$ \\
\hline Coder consensus & 948 & 928 & 944 & 13430 & 13482 & 13354 \\
\hline Coder differences & 72 & 92 & 76 & 646 & 594 & 722 \\
\hline$r_{H}$ Coefficient & 0.93 & 0.91 & 0.93 & 0.95 & 0.96 & 0.95 \\
\hline Average $r_{H}$ & \multicolumn{3}{|c|}{0.92} & \multicolumn{3}{c|}{0.95} \\
\hline Krippendorff's $\alpha$ & 0.85 & \multicolumn{3}{c|}{0.80} \\
\hline
\end{tabular}

Regarding the services in total, each coder had to judge 7038 items. The three coders achieved a very good reliability for Holsti's Coefficient [39] and an acceptable degree of reliability for the Krippendorff's $\alpha$ [34] (see Table 2). Finally, an expert panel of senior researchers with high expertise in the field of e-marketplaces discussed all remaining discrepancies (2202 items) and made the final decisions to harmonize coder inconsistencies. 


\subsection{Corona-Effects: Methodology \& Questionnaire of the Telephone Interviews}

The dynamic and complex development since the outbreak of the coronavirus was analyzed with an additional explorative study using semi-structured telephone interviews [40]. We chose this method because of its efficiency (time and personnel expenditures [41]) and its accordance with the social distancing requirements [42]. The interview guideline contained 11 standard questions to address three main topics: 1) the reasons for the chosen LSP type and the implemented services, 2) the experiences and new developments of the LSP during the corona crisis, and 3) strategies to sustain the LSPs business model after the corona crisis.

To address the dynamics in the development and the potential impact of the lockdown, we added two customized extensions, the first including three questions for LSPs created as a response to the lockdown, and the second including seven questions for LSPs that had been established already before the corona crisis. The questionnaire used two types of questions, one with a dichotomous 5-point Likert scale to capture the intensity of the answers, the other for open questions. We explained both types to the interview partners in order to avoid any biases like the "Response-Order-Effect" [43].

\subsection{Corona-Effects: Sample \& Documentation of the Telephone Interviews}

To examine the current impact of the corona crisis on LSPs, we used the LSP collection provided by the EU-funded research project "City Lab Südwestfalen". The "City Lab Südwestfalen" collected the data to offer an overview of existing and new LSPs since the corona crisis from partner municipalities in the region of South Westphalia in Germany [44]. In total, we interviewed 26 LSP providers (9 established LSPs; 17 new LSPs) in June 2020. The average interview lasted for 30 minutes. We used the "Footin-the-Door-Technique“, calling two times: In the first call, we introduced the topic, and made an appointment for the actual interview (second call) [41]. We used this approach to decrease the refusal rate and to increase the quality of the data [45]. The responses were collected in an excel sheet during the interviews.

From the interviewed platforms, 21 out of the 26 LSPs represent s Store Locator Platform (81\%), one a Product Catalog Platform (4\%), and four a Full Transaction Platform (15\%).

\section{$4 \quad$ Results}

\subsection{Results Content Analysis: Development of LSPs since 2016}

To address our first and second sub research question, we discuss our findings of the content analysis and compare them with the findings from 2016 (see Table 3) for 21 German platforms [17]. The findings confirm the derived platform types from 2016 [17], now identifying 65 Store Locator Platforms, 3 Product Catalog Platforms, 10 Product Enquiry Platforms, 2 Affiliate Transaction Platforms, and 22 Full Transaction Platforms. The current study reveals that the majority of platforms follows the "Strictly 
Local Approach" (89 out of 102) and represents Store Locator Platforms, focusing mostly on information and communication functionality. In contrast to this, the 2016 study identified the majority of LSPs as Full Transaction Platforms [17]. Furthermore, platforms which follow a "Scaling Local Approach" (2019: 12 Full Transaction and one Affiliate Transaction Platform) mainly focus on transaction and fulfilment functionality, while neglecting to utilize the locational advantages of LOOROs.

The 102 analyzed platforms still provide most of the same 69 digital services that were identified in the preliminary study from 2016 [17]. Concerning the use of location in the service landscape, of the 69 digital services, 40 are location-independent and 29 are location-dependent services. The 69 services support the different functions of emarketplaces [23], [24]: Information \& recommendation services, communication \& support, and payment \& fulfillment services. The following tables (see Table 3-7) show the number of offered services by each LSP type for the examination in 2016 and 2019. Reading example: 1) From the sample of 2016, Store Locator Platforms have offered $21.88 \%$ of the identified location-enabled services. 2) From the sample of 2019, Store Locator Platforms have offered on average of $9.88 \%$ of the identified services. Calculation example for the services: 65 LSPs $* 16$ location-enabled services $=1040$ (e.g., see Table 3).

Table 3: Service landscape offered by Store Locator Platforms

\begin{tabular}{|l|c|c|c|c|}
\hline Sample & 2016 & \multicolumn{3}{|c|}{2019} \\
\hline $\begin{array}{l}\text { Store Locator } \\
\text { Platforms }\end{array}$ & Total & Total & $\begin{array}{c}\text { Strictly } \\
\text { Local }\end{array}$ & $\begin{array}{c}\text { Scaling } \\
\text { Local }\end{array}$ \\
\hline Number of Platforms & 2 & \multicolumn{2}{|c|}{65} & -- \\
\hline $\begin{array}{l}\text { Location-Enabled } \\
\text { Services }\end{array}$ & $\begin{array}{c}21.88 \% \\
(7 \text { of } 32)\end{array}$ & $\begin{array}{c}19.04 \% \\
(198 \text { of } 1040)\end{array}$ & $\begin{array}{c}19.04 \% \\
(198 \text { of } 1040)\end{array}$ & - \\
\hline Location-Based Services & $\begin{array}{c}215.38 \% \\
(4 \text { of } 26)\end{array}$ & $\begin{array}{c}3.67 \% \\
(31 \text { of } 845)\end{array}$ & $\begin{array}{c}3.67 \% \\
(31 \text { of } 845)\end{array}$ & -- \\
\hline $\begin{array}{l}\text { Location-Independent } \\
\text { Services }\end{array}$ & $\begin{array}{c}16.25 \% \\
(13 \text { of } 80)\end{array}$ & $\begin{array}{c}8.23 \% \\
(214 \text { of } 2600)\end{array}$ & $\begin{array}{c}8.23 \% \\
(214 \text { of } 2600)\end{array}$ & -- \\
\hline $\begin{array}{l}\text { Average No. of Total } \\
\text { Services }\end{array}$ & $\begin{array}{c}17.39 \% \\
(24 \text { of } 138)\end{array}$ & $\begin{array}{c}9.88 \% \\
(443 \text { of } 4485)\end{array}$ & $\begin{array}{c}9.88 \% \\
(443 \text { of } 4485)\end{array}$ & -- \\
\hline
\end{tabular}

For Store Locator Platforms, we found a striking increase for location-enabled services, like information (e.g., contact data or the address of LOOROs) or communication \& support services (e.g., loyalty cards), location-based services (e.g., outdoor navigation as a navigation service), and location-independent services (e.g., support via E-Mail as a communication \& support service) in absolute values. Concerning Product Catalog Platforms, we also found a higher offering of location-enabled services (e.g., information) compared to 2016. This also holds for location-based (e.g., advertisement or discounts) and location-independent services in absolute values (see Table 4). Product Enquiry Platforms provided, in general, a higher level of location-dependent services, especially reserve \& collect. Moreover, we found a strong increase in numbers of recommendation services (e.g., product recommendations, further products of the retailers) as location-independent services (see Table 5). 
Table 4: Service landscape offered by Product Catalog Platforms

\begin{tabular}{|l|c|c|c|c|}
\hline Sample & 2016 & \multicolumn{3}{|c|}{2019} \\
\hline $\begin{array}{l}\text { Product Catalog } \\
\text { Platforms }\end{array}$ & Total & Total & $\begin{array}{c}\text { Strictly } \\
\text { Local }\end{array}$ & $\begin{array}{c}\text { Scaling } \\
\text { Local }\end{array}$ \\
\hline Number of Platforms & 2 & \multicolumn{2}{|c|}{3} & -- \\
\hline Location-Enabled & $\begin{array}{c}28.13 \% \\
(9 \text { of } 32)\end{array}$ & $\begin{array}{c}22.92 \% \\
(11 \text { of } 48)\end{array}$ & $\begin{array}{c}22.92 \% \\
(11 \text { of } 48)\end{array}$ & -- \\
Services & $\begin{array}{c}7.69 \% \\
(2 \text { of } 26)\end{array}$ & $\begin{array}{c}20.51 \% \\
(8 \text { of } 39)\end{array}$ & $\begin{array}{c}20.51 \% \\
(8 \text { of } 39)\end{array}$ & -- \\
\hline Location-Based Services & $\begin{array}{c}17.50 \% \\
(14 \text { of } 80)\end{array}$ & $\begin{array}{c}15.00 \% \\
(18 \text { of } 120)\end{array}$ & $\begin{array}{c}15.00 \% \\
(18 \text { of } 120)\end{array}$ & -- \\
\hline Location-Independent & $\begin{array}{c}18.12 \% \\
(25 \text { of } 138)\end{array}$ & $\begin{array}{c}17.87 \% \\
(37 \text { of } 207)\end{array}$ & $\begin{array}{c}17.87 \% \\
(37 \text { of } 207)\end{array}$ & - \\
\hline Services & \multicolumn{4}{|l}{} \\
Services &
\end{tabular}

Table 5: Service landscape offered by Product Enquiry Platforms

\begin{tabular}{|l|c|c|c|c|}
\hline Sample & 2016 & \multicolumn{3}{|c|}{2019} \\
\hline $\begin{array}{l}\text { Product Enquiry } \\
\text { Platforms }\end{array}$ & Total & Total & $\begin{array}{c}\text { Strictly } \\
\text { Local }\end{array}$ & $\begin{array}{c}\text { Scaling } \\
\text { Local }\end{array}$ \\
\hline Number of Platforms & 5 & \multicolumn{2}{|c|}{10} & -- \\
\hline $\begin{array}{l}\text { Location-Enabled } \\
\text { Services }\end{array}$ & $\begin{array}{c}20.00 \% \\
(16 \text { of } 80)\end{array}$ & $\begin{array}{c}23.75 \% \\
(38 \text { of } 160)\end{array}$ & $\begin{array}{c}23.75 \% \\
(38 \text { of } 160)\end{array}$ & - \\
\hline Location-Based Services & -- & $\begin{array}{c}2.31 \% \\
(3 \text { of } 130)\end{array}$ & $\begin{array}{c}2.31 \% \\
(3 \text { of } 130)\end{array}$ & -- \\
\hline $\begin{array}{l}\text { Location-Independent } \\
\text { Services }\end{array}$ & $\begin{array}{c}17.50 \% \\
(35 \text { of } 200)\end{array}$ & $\begin{array}{c}13.50 \% \\
(54 \text { of } 400)\end{array}$ & $\begin{array}{c}13.50 \% \\
(54 \text { of } 400)\end{array}$ & -- \\
\hline $\begin{array}{l}\text { Average No. of Total } \\
\text { Services }\end{array}$ & $\begin{array}{c}14.48 \% \\
(51 \text { of } 345)\end{array}$ & $\begin{array}{c}13.77 \% \\
(95 \text { of } 690)\end{array}$ & $\begin{array}{c}13.77 \% \\
(95 \text { of } 690)\end{array}$ & -- \\
\hline
\end{tabular}

In general, we found a decrease of location-dependent and location-independent services for affiliate platforms. Regarding location-independent services, platforms with a "Scaling Local Approach" offer more payment \& billing options than platforms with a "Strictly Local Approach". However, platforms with a "Scaling Local Approach" offer slightly more location-based services (see Table 6). This service pattern for the "Scaling Local Approach" also holds true for Full Transaction Platforms and is in line with their focus on non-local customers who benefit most from such services. Nevertheless, the location-enabled services and location-based services decrease in comparison to 2016 for Full Transaction Platforms (see Table 7). In general, the results also confirm that platforms with transaction and fulfillment functionality, e.g., Affiliate Transaction Platforms and Full Transaction Platforms, offer more services than information and communication focused platforms, like e.g., Store Locator Platforms. Concerning the different platform types, the typical platform with a "Strictly Local Approach" is a Store Locator or Product Catalog Platform, while platforms with a "Scaling Local Approach" tend to be Full Transaction Platforms. 
Table 6: Service landscape offered by Affiliation Platforms

\begin{tabular}{|c|c|c|c|c|}
\hline Sample & 2016 & \multicolumn{3}{|c|}{2019} \\
\hline Affiliation Platforms & Total & Total & $\begin{array}{l}\text { Strictly } \\
\text { Local }\end{array}$ & $\begin{array}{l}\text { Scaling } \\
\text { Local }\end{array}$ \\
\hline Number of Platforms & 4 & 2 & 1 & 1 \\
\hline $\begin{array}{l}\text { Location-Enabled } \\
\text { Services }\end{array}$ & $\begin{array}{l}34.44 \% \\
\text { (22 of } 64) \\
\end{array}$ & $\begin{array}{l}40.63 \% \\
(13 \text { of } 32)\end{array}$ & $\begin{array}{l}43.75 \% \\
(7 \text { of } 16)\end{array}$ & $\begin{array}{l}37.50 \% \\
(6 \text { of } 16)\end{array}$ \\
\hline Location-Based Services & $\begin{array}{l}11.54 \% \\
(6 \text { of } 52)\end{array}$ & $\begin{array}{l}11.54 \% \\
\text { (3 of 26) }\end{array}$ & $\begin{array}{l}15.38 \% \\
(2 \text { of } 13)\end{array}$ & $\begin{array}{l}7.69 \% \\
(1 \text { of } 13) \\
\end{array}$ \\
\hline $\begin{array}{l}\text { Location-Independent } \\
\text { Services }\end{array}$ & $\begin{array}{l}24.38 \% \\
(39 \text { of } 160)\end{array}$ & $\begin{array}{l}21.25 \% \\
(17 \text { of } 80)\end{array}$ & $\begin{array}{l}17.50 \% \\
(7 \text { of } 40)\end{array}$ & $\begin{array}{l}25.00 \% \\
(10 \text { of } 40)\end{array}$ \\
\hline $\begin{array}{l}\text { Average No. of Total } \\
\text { Services }\end{array}$ & $\begin{array}{l}24.28 \% \\
(67 \text { of } 276)\end{array}$ & $\begin{array}{l}23.91 \% \\
\text { (33 of 138) }\end{array}$ & $\begin{array}{l}23.19 \% \\
\text { (16 of } 69)\end{array}$ & $\begin{array}{l}24.64 \% \\
(17 \text { of } 69)\end{array}$ \\
\hline
\end{tabular}

Table 7: Service landscape offered by Full Transaction Platforms

\begin{tabular}{|l|c|c|c|c|}
\hline Sample & 2016 & \multicolumn{3}{|c|}{2019} \\
\hline $\begin{array}{l}\text { Full Transaction } \\
\text { Platforms }\end{array}$ & Total & Total & $\begin{array}{c}\text { Strictly } \\
\text { Local }\end{array}$ & $\begin{array}{c}\text { Scaling } \\
\text { Local }\end{array}$ \\
\hline Number of Platforms & 8 & 22 & 10 & 12 \\
\hline $\begin{array}{l}\text { Location-Enabled } \\
\text { Services }\end{array}$ & $\begin{array}{c}37.50 \% \\
(48 \text { of } 128)\end{array}$ & $\begin{array}{c}24.72 \% \\
(87 \text { of } 352)\end{array}$ & $\begin{array}{c}25.00 \% \\
(40 \text { of } 160)\end{array}$ & $\begin{array}{c}24.48 \% \\
(47 \text { of } 192)\end{array}$ \\
\hline Location-Based Services & $\begin{array}{c}5.77 \% \\
(6 \text { of } 104)\end{array}$ & $\begin{array}{c}1.05 \% \\
(3 \text { of } 286)\end{array}$ & $\begin{array}{c}1.54 \% \\
(2 \text { of } 130)\end{array}$ & $\begin{array}{c}0.64 \% \\
(1 \text { of } 156)\end{array}$ \\
\hline $\begin{array}{l}\text { Location-Independent } \\
\text { Services }\end{array}$ & $\begin{array}{c}34.38 \% \\
(110 \text { of } 320)\end{array}$ & $\begin{array}{c}32.05 \% \\
(282 \text { of } 880)\end{array}$ & $\begin{array}{c}29.75 \% \\
(119 \text { of } 400)\end{array}$ & $\begin{array}{c}33.96 \% \\
(163 \text { of } 480)\end{array}$ \\
\hline $\begin{array}{l}\text { Average No. of Total } \\
\text { Services }\end{array}$ & $\begin{array}{c}29.71 \% \\
(164 \text { of } 552)\end{array}$ & $\begin{array}{c}24.51 \% \\
(372 \text { of } 1518)\end{array}$ & $\begin{array}{c}23.33 \% \\
(161 \text { of } 690)\end{array}$ & $\begin{array}{c}25.48 \% \\
(211 \text { of } 828)\end{array}$ \\
\hline
\end{tabular}

\subsection{Results of the Telephone Interviews: Corona-Effects}

The results of the telephone interviews will be discussed along the three defined guiding topics: 1) reasons for the chosen LSP type and the implemented services, 2) experiences and new developments during the corona crisis, and 3) strategies to sustain the LSPs after the corona crisis.

\section{1) Reasons for the Chosen LSP Type and the Implemented Services}

It turned out that the idea and the implementation of a LSP as a response to the lockdown was spontaneously driven by various actors, mostly city marketing / administration, or also regional business development units. Just five of the contacted LSP providers explained that they had planned the LSP implementation already before the crisis and that the coronavirus only accelerated the process. Contrary, nine interviewees reported that no LSP was in preparation before the lockdown, while six confirmed that they had some basic ideas before. The institutional background of the platform providers itself also seems to influence the chosen LSP type and the choice of implemented services. For example, city-related actors, like city marketing, apparently 
focus on supporting their local stationary retailers by providing only rudimentary information on Store Locator Platforms. In order to shed more light on their objectives, we asked the interviewees to rate statements on their intentions using a five-point Likert scale (from strongly disagree to strongly agree). Five out of nine providers of the already established platforms, and six out of 17 providers of the newly created LSPs, agreed to the statement "It is intended to prevent customers from migrating to large online retailers in general". Surprisingly, the majority of the providers of the newly created platforms rated this item neutral (eight out of 17). The statement "It is intended to generate sales (parallel to stationary retailing)" was only raised towards providers of Full Transaction Platforms. Two providers of existing platforms agreed with the statement, while one provider of a new platform rather disagreed, stating that "revenue via the platform should be understood as a bonus, which exceeds the monthly fee but not as a second income source". Other interviewees summarized their intentions as "improving the digital visibility of their city with its local retailers as a shopping [...] location" or as "[...] supporting local retailers so that customers don't buy on Amazon".

The timeframe for implementing the new LSPs ranged from overnight (5 LSPs out of 17) to within two weeks (11 out of 17), except for one Full Transaction Platform that was developed in three weeks. In comparison, the already established platforms needed six months up to two years for Store Locator Platforms (six out of nine) and two months up to one year for Full Transaction Platforms. Regarding problems that occurred during the implementation of the platforms and the digital services, the interviewees reported challenges setting up the payment infrastructure or also missing inventory management systems as a necessary backbone for additional digital services.

\section{2) Experiences and new developments during the corona crisis}

One major finding is that all existing LSPs extended their services during the corona crisis, e.g., with coupons, more detailed information on delivery options or general information about shopping with corona restrictions in place. During the lockdown, four existing LSPs reported a dynamic increase in numbers of connected retailers, while four existing LSPs reported a regular growth. One platform has extended its area of operation from three to ten regions. Furthermore, it seems that the corona crisis has boosted the attractiveness of LSPs for LOOROs. We asked the participants to evaluate the willingness of LOOROs to join and to actively use the platform or cooperate with the platform providers, e.g., regarding content creation (store and product information) (five-point Likert scale from very easy to very difficult). All interviewees reported that it became easier for them to win new LOOROs for their platforms compared to the precoronavirus situation. They further stated that also content creation by the LOOROs themselves and on behalf of them (by the LSP provider) became easier. 15 out of 17 new LSPs (3 out of 9 existing LSPs) rated the content creation by LOOROs as easy, and 14 out of 17 new LSPs ( 3 out of 9 existing LSPs) rated the content creation on behalf of their LOOROs as easy. According to the providers of Store Locator Platforms, one primary reason for the high willingness of LOOROs to participate and for the perceived ease regarding content creation was the collection of necessary retailer information with a survey or an online document. 


\section{3) Strategies to Sustain the LSPs After the Corona Crisis}

All LSPs reported decreasing interest and decreasing participation of LOOROs since the easing of the coronavirus restrictions. Accordingly, LSP providers now focus on incentivizing active participation on their platforms. As financial incentives to participate, 21 out of 27 interviewed LSP providers do not charge any membership fees from LOOROs. One of the already established LSPs paused the monthly fee until June 2020. Another existing LSP decided to offer free online visibility for new LOOROs, while already participating LOOROs need to pay a fee. Only two existing LSPs did not change their pricing model, and two of the new LSPs offer free participation for a specific period from six months to one year. 15 out of 17 new LSPs agreed to the statement (five-point Likert scale from strongly disagree to strongly agree) that the platform is designed to ensure the short-term survival of LOOROs during the corona crisis. 14 out of 17 agreed to the statement that the LSPs aim to strengthen the online visibility of LOOROs also after the corona crisis. The majority of the already established platforms (seven out of nine), and also the majority of the new platforms (13 out of 17) intends to improve resp. extend their platform content and also their digital service landscape, e.g., by adding more and better pictures in product and retailer descriptions, or by implementing click \& collect functionality.

\section{Conclusion}

\subsection{Discussion}

Regarding the first sub research question "How did the types of German LSPs develop between 2016 and 2019?”, Our results show that the LSP market changed from a majority of Full Transaction Platforms to a majority of Store Locator Platforms. The majority of LSPs follows a "Strictly Local Approach". This matches other findings from research that state that LOOROs prefer LSPs with a clear focus on local customers over global online platforms with intense price competition [46]. Nevertheless, we found 13 LSPs that have loosened their local self-restrictions to address also non-local customers, now following a "Scaling Local Approach". While this opens new market segments, it also makes the platform less distinguishable from other shopping sites. In contrast to former findings, our results show that LSPs with a "Scaling Local Approach" are perceived to act contrarily to the objectives and wishes of their LOORO target group [26]. Furthermore, from the 2016 sample, only eight platforms still exist. Notably, the high number of closedowns of Full Transaction Platforms stands out, confirming other studies [46]. Apparently, the business model of a Local Shopping Platform still lacks proof of concept.

Concerning the second sub research question: "How did the digital services offered by German LSPs develop between 2016 and 2019?”, we found that LSPs still fall short in providing services that utilize the locational proximity between shops and customers. It seems that LSPs are still not interested in strengthening their locational position and do not support LOOROs to make or sustain profit by attracting customers to their stores [26]. This result indicates that there is no fundamental change in the service landscape 
compared to 2016 [17]. The implemented services can be considered as one-way communication, providing only general information (e.g., opening hours), instead of facilitating interaction between LOOROs and customers [46].

Finally, with regard to the third sub research question: "How has the corona crisis affected the development of LSPs?”, we found that the corona crisis clearly pushed the implementation of LSPs and also reduced the implementation periods drastically. This result shows that the coronavirus is a game changer and that the pandemic is fostering the willingness of LOOROs to follow e-commerce trends. Accordingly, the issue of convincing LOOROs to join the platforms has become much easier. Witt LOOROs focusing on the information-centric platform types, the new platforms provided a quick and easy measure in face of the corona restrictions to stay in business. Former studies confirm the importance of low entry barriers for LOOROs [49]. On the other hand, as LSPs have not substantially further developed there service offers, it needs to be doubted that they will effectively support LOOROs in their digital transformation and help them sustain or even grow their businesses. This is supported by the visibly decreasing interest in the newly created LSPs since the easing of the corona restrictions. LOOROs still seem hesitant and not fully convinced of the positive impact of LSPs.

\subsection{Practical Implications}

Several lessons can be learned from this study. First, current LSP providers are still not utilizing the locational advantage of their local retailers, although "Location-depended Services" need to be considered as an important success factor [17], [26]. Moreover, platforms with a "Scaling Local Approach" loosen their focus on local customers, running the risk of discouraging LOOROs from joining their platforms. LSP providers need to understand that they depend on the existence of LOOROs and that only strong local retail partners can provide a sustainable basis for their platforms [17]. However, LOOROs also need to understand that customers want convenience and that they prefer local shopping malls / agglomerations of local shops over individual online presences [47]. Therefore, LOOROs should also invest in cooperative online initiatives like LSPs. Once connected to a LSP, they should actively improve the visibility of their cooperation through active link-building [48]. Furthermore, LOOROs should learn from the recent lockdown that digitalization is now and not in the far future. They need to overcome their internal adaption barriers and check if their self-perception still matches their actual competitive situation and customer expectations [2].

Second, our study shows that entry barriers matter. LSP providers need to create tools that facilitate and ease the active use of their platforms for LOOROs, this way also reducing entry barriers for them [49].

The lockdown in the context of the spread of the coronavirus lead to an erratic increase of LSPs and moved many new retailers on the platforms. Store Locator Platforms with their low level of digital services currently dominate the LSP market in Germany (see RQ1). Forty-four out of 53 platforms from the data sample 2019 with a "Strictly Local Approach" turned out to be Store Locator Platforms, run by city-related units. Supporting this finding, 10 out of 17 of the new LSPs from the 2020 data sample are run by city-related actors. It is questionable if Store Locator Platforms with their 
currently low service level can substantially contribute to local retail and help to sustain high street shopping. In line with this evaluation, the retailers also expressed their doubts over the ability of Store Locator Platforms to help them reach customers [26]. One-way communication on passive, information-centric platforms might not be enough. More services and urban functions need to be implemented on the platforms to attract and keep customers on the platforms [46]. The platform providers should thereby actively make use of the locational proximity between the retailers and customers with the help of "Location-based" and "Location-enabled Services", as this will strengthen and harness their unique selling proposition as against global platforms.

\subsection{Limitations and Directions for Future Research}

To the best of our knowledge, we found 102 platforms in Germany with the help of the defined keyword list. Future research should extend the regional scope and the keyword list. Thereby, modern technologies like Web Crawlers could help to improve the quality and the completeness of the search process. Secondly, the perspective of retailers needs to be further investigated in a qualitative analysis. Finally, a quantitative, conclusive research approach should follow this first explorative study to validate our findings.

\section{References}

1. IFH Köln: Handelsszenario 2030: Wachtsumsparadoxen im deutschen Einzelhandel. https://www.ifhkoeln.de/pressemitteilungen/details/handelsszenario-2030wachstumsparadoxon-im-deutschen-einzelhandel/ (Accessed: 13.07.2020)

2. Bollweg, L., Lackes, R., Siepermann, M., Weber, P.: Digitalization of Local OwnerOperated Retail Outlets: Between Customer Demand, Competitive Challenge and Business Persistence. 15 WI 2020, 1004-1018 (2020)

3. Koren, M., Peto, R.: It's retail stores and restaurants, not farms and fisheries that suffer most from social distancing. VoxEU.org 2020, https://voxeu.org/article/it-s-retail-stores-andrestaurants-not-farms-and-fisheries-suffer-most-social-distancing? (Accessed: 13.07.2020)

4. Coyle, D., Nguyen, D.: The impact of Covid-19 on the value of online goods. https://voxeu.org/article/impact-covid-19-value-online-goods (Accessed: 24.08.2020)

5. Statistisches Bundesamt (Destatis): Pressemitteilung Nr. 151 vom 30. April 2020. https://www.destatis.de/DE/Presse/Pressemitteilungen/2020/04/PD20_151_45212.html (Accessed: 13.07.2020)

6. Statistisches Bundesamt (Destatis): Pressemitteilung Nr. 245 vom 1. Juli 2020. https://www.destatis.de/DE/Presse/Pressemitteilungen/2020/07/PD20_245_45212.html (Accessed: 13.07.2020)

7. Bundesfinanzministerium (BMF) 2020."Europäische Antwort auf Corona“. https://www.bundesfinanzministerium.de/Content/DE/Standardartikel/Themen/Schlaglicht er/Corona-Schutzschild/2020-03-27-eurogruppe-rat.html (Accessed: 13.07.2020)

8. Bosio, E., Djankov, S.: Southern European and emerging market firms are under severe distress. VoxEU.org 2020, https://voxeu.org/article/southern-european-and-emergingmarket-firms-are-under-severe-distress (Accessed: 13.07.2020)

9. Berman, B.: Flatlined: Combatting the death of retail stores. Business Horizons 62(1), 7582 (2019) 
10. Grewal, D., Roggeveen, A., L., Nordfält, J.: The Future of Retailing. Journal of Retailing 93(1), 1-6 (2017)

11. Wiener, M., Hoßbach, N., Saunders, C.: Omnichannel businesses in the publishing and retailing industries: Synergies and tensions between coexisting online and offline business models. Decision Support Systems 109, 15-26 (2018)

12. Vize, R., Coughlan, J., Kennedy, A., Ellis-Chadwick, F.: Technology Readiness in a B2B Online Retail Context: An Examination of Antecedents and Outcomes. Ind. Market. Manage. 42(6), 909-918 (2013)

13. Rahayu, R., Day, J.: Determinant Factors of E-commerce Adoption by SMEs in Developing Country: Evidence from Indonesia. Procd. Soc. Behv. 195, 142-150 (2015)

14. Kabanda, S., Brown, I.: A Structuration Analysis of Small and Medium Enterprise (SME) adoption of E-Commerce: The case of Tanzania. Telemat. Inform. 34(4), 118-132 (2017)

15. Kurnia, S., Choudrie, J., Mahbubur, R.M., Alzougool, B.: E-commerce Technology Adoption: A Malaysian Grocery SME Retail Sector Study. J. Bus. Res. 68(9), 1906-1918 (2015)

16. IFH Köln: Der Handel nach Corona: Digitale Konzepte als Zukunftsperspektive, https://www.ifhkoeln.de/pressemitteilungen/details/der-handel-nach-corona-digitalekonzepte-als-zukunftsperspektive/ (Accessed: 13.07.2020)

17. Bärsch, S., Bollweg, L., Lackes, R., Siepermann, M., Weber, P., Wulfhorst, V.: Local Shopping Platforms - Harnessing Locational Advantages for the Digital Transformation of Local Retail Outlets: A Content Analysis. 14 WI 2019, 602-618 (2019)

18. Petersen, K.J., Ogden, J.A., Carter, P.L.: B2B E-marketplaces: A Typology by Functionality. Int. J. Phys. Distr. Log. 37(1), 4-18 (2007)

19. Digital Pioneers: Local Commerce: Die sinnlosen Marktplätze von nebenan. https://t3n.de/news/local-commerce-sinnlosen-934455/ (Accessed: 13.07.2020)

20. Sandberg, K.W., Håkansson, F.: Barriers to Adapt Ecommerce by Rural Microenterprises in Sweden: A Case Study. International Journal of Knowledge and Research in Management and E-Commerce 4(1), 1-7 (2014)

21. Stockdale, R., Standing, C.: Benefits and Barriers of Electronic Marketplace Participation: an SME Perspective. Journal of Enterprise Information Management 17(4), 301-311 (2004)

22. Bollweg, L., Lackes, R., Siepermann, M., Weber, P.: The Role of Location Dependent Services for the Success of Local Shopping Platforms. Conference DigEx 2019

23. Bakos, Y.: The Emerging Role of Electronic Marketplaces on the Internet. Communications of the ACM 41(8), 35-42 (1998)

24. Standing, S., Standing, Love, C.: A Review of Research on E-marketplaces 1997-2008. Decis. Support Syst. 49(1), 41-51 (2010)

25. Pan, X., Shankar, V., Ratchford, B.T.: Price competition between pure play versus bricksand-clicks e-tailers. Advances in Applied Microeconomics 11, 29-61 (2002)

26. Berendes, C., I., zur Heiden, P., Niemann, M., Hoffmeister, B., Becker, J.: Usage of Local Online Platforms in Retail: Insights From Retailers Expectations. 28th ECIS2020 - A Virtual AIS Conference

27. Zheng, W., Wang, X.: An Explorative Study of Industry Influences: On Vertical E-marketplaces' Adoption of E-procurement Auction. Inf. Syst. E-Bus. Manag. 6(4), 321-340 (2008)

28. Blum, B., Goldfarb, A.: Does the internet defy the law of gravity? Journal of International Economics 70(2), 384-405 (2006)

29. Iyer, K.N., Germain, R., Frankwick, G.L.: Supply chain B2B E-commerce and Time-based Delivery Performance. Int. J. Distr. Log. 34(8), 645-661 (2004)

30. Kim, T.Y., Dekker, R., Heij, C.: Cross-Border Electronic Commerce: Distance Effects and Express Delivery in European Union Markets, International Journal of Electronic Commerce, 21(2), 184-218 (2017) 
31. Massad, N., Heckman, R., Crowston, K.: Customer satisfaction with electronic service encounters. International Journal of Electronic Commerce, 10(4), 73-104 (2006)

32. Saeed, K.A., Grover, V., Hwang, Y.: The relationship of e-commerce competence to customer value and firm performance: An empirical investigation. Journal of Management Information Systems, 22(1), 223-256 (2005)

33. Krippendorff, K.: Validity in Content Analysis. In: E. Mochmann (Ed.), Computerstrategien für die Kommunikationsanalyse, pp. 69-112. Campus Verlag, Frankfurt am Main (1980)

34. Krippendorff, K.: Content Analysis. An Introduction to Its Methodology (2nd ed.), p. 237. Sage, Thousand Oaks (2004)

35. Mayring, P.: Qualitative Inhaltsanalyse. Handbuch qualitative Forschung in der Psychologie, pp. 601-613. Springer VS, Wiesbaden (2010)

36. Raupp, J., Vogelsang, J.: Medienresonanzanalyse. Eine Einführung in Theorie und Praxis (1. Aufl.). pp. 119-175. Springer VS, Wiesbaden (2009)

37. Tinsley, H.E., Weiss, D.J.: Interrater Reliability and Agreement of Subjective Judgements. J. Couns. Psychol. 22(4), 358-376 (1975)

38. Tinsley, H.E., Weiss, D.J.: Interrater Reliability and Agreement. In: Tinsley, H.E.A., Brown, S.D. (eds.) Handbook of Applied Multivariate Statistics and Mathematical Modeling, pp. 95-124. Academic Press, San Diego (2000)

39. Holsti, O.R.: Content Analysis for the Social Sciences and Humanities, 138-141. AddisonWesley, Reading (1969)

40. Frey, J.H.: Survey Research by Telephone. p. 29. Beverly Hills (1989).

41. Döring, N., Bortz, J.: Forschungsmethoden und Evaluation in den Sozial-und Humanwissenschaften, pp. 373-375. Springer. (2016)

42. Die Landesregierung Nordrhein-Westfalen 2020. Aktuelle FAQ zur Corona-Pandemie. https://www.land.nrw/corona (Accessed: 01.06.2020)

43. Schumann, H., Presser, S.: Questions and Answers in Attitude Surveys. New York (1981)

44. City Lab Südwestfalen: Übersicht lokaler Online-Marktplätze der Partnerkommunen. https://www.citylab-swf.de/news/uebersicht-lokaler-online-marktplaetze-derpartnerkommunen/ (Accessed: 13.05.2020)

45. Dillman, D.A., Gallegos J., Frey., J.H.: Reducing Refusal Rates for Telephone InterviewsPublic Opinion Quartely 40, 66-78 (1976).

46. Schade, K., Hübscher, M., Korzer, T.: Smart Retail in Smart Cities: Best Practice Analysis of Local Online Platforms. In Proceedings of the 15th ICETE - Volume 1, 147-157 (2018)

47. Teller, C., Alexander, A., Floh, A.: The impact of competition and cooperation on the performance of a retail agglomeration and its stores. Ind. Mark. Manag. 52, 6-17 (2016)

48. Bollweg, L., Lackes, R., Siepermann, M., Weber, P.: The Role of E-Intermediaries in Local Retail Hyperlink Networks: A Hyperlink Network Analysis. MKWI (2018)

49. Delgado-de Miguel, J.-F., Menchero, T., B.-L., Esteban-Navarro, M.-A., Garcia-Madurga, M.-A.: Proximity Trade and Urban Sustainability: Small Retailers’ Expectations Towards Local Online Marketplaces. Sustainability 11, 1-20 (2019) 